\title{
Politička i vojna situacija i oružane snage Kraljevine Srba, Hrvata i Slovenaca / Jugoslavije u informacijama, izvještajima i analizama II. odjela Glavnoga stožera / Generalštaba Vojske Republike Poljske
}

\author{
ANDRZEJ KRZAK \\ Uniwersytet Humanistyczno-Przyrodniczy im. \\ Jana Długosza w Częstochowie \\ Częstochowa, Poljska \\ stanczyk2@o2.pl
}

Kraljevina Srba, Hrvata i Slovenaca / Jugoslavija nije bila glavni predmet operativnih aktivnosti poljskih vojnih obavještajnih službi. Ipak, zbog provođenih i planiranih strateških projekata vezanih za državnu obranu postavljeni su zadaci pribavljanja podataka prije svega o vojnom potencijalu zemlje, njezinoj politici prema susjednim državama i mogućnosti prodaje poljskoga naoružanja. Za rukovodstvo poljske države, kao i za obavještajne časnike, tajno širenje jugoslavenske vojske i politički i vojni odnosi s Čehoslovačkom i Rumunjskom u okviru savezničkih obveza u Maloj Antanti nesumnjivo su bili zanimljivi. Analizirani dokumenti pokazuju da se Jugoslavija poljskoj vojsci činila državom sa složenom unutarnjom situacijom koja nastoji održati versailleski poredak i ima brojne znanstvene i kulturne veze s Poljskom. S druge strane zapaženo je da Kraljevina simpatizira Rusiju, Češku i Njemačku, kao i brojnu bjelogardijsku dijasporau, za koju se smatralo da su se u nju infiltrirali boljševici, što je zasigurno utjecalo na odluke o potrebi njezina uključivanja u obavještajni opseg II. odjela te političkih i vojnih procjena Kraljevine Jugoslavije i njezinih oružanih snaga. 
Ključne riječi: II. odjel Generalštaba poljske vojske; vojni ataše; Vojska Kraljevine Srba, Hrvata i Slovenaca / Jugoslavije; vojna diplomacija; obavještajne i informacijske aktivnosti

\section{Uvod}

Djelatnost poljske vojne diplomacije u jugoslavenskoj državi od 1919. do 1939. i poslije ostaje jedno od najzanimljivijih i, nažalost, manje poznatih istraživačkih područja. Položaj Republike Poljske, obnovljene nakon 123 godine podjele, bio je složen, posebno zato što je na istoku i zapadu graničila s dvije sile koje nisu prihvatile odredbe Versailleskoga ugovora i cilj im je bio promijeniti ih. Situacija nije bila mnogo bolja na jugu i sjeveroistoku (granice s Litvom i Čehoslovačkom). Samo se rumunjska granica mogla opisati kao stabilna ili čak prijateljska. Geopolitička situacija Republike Poljske između 1918. i 1939. nesumnjivo je u velikoj mjeri implicirala opasnost od susjeda. Utjecalo je to na vanjsku i na obrambenu politiku države. Da bi osigurale neovisno postojanje obnovljene države, jedan od glavnih problema s kojima su se suočile vlade u tom razdoblju bilo je osiguranje komunikacijske povezanosti Poljske i njezinih saveznika u zapadnoj Europi. Stoga je provođenje glavnih vanjskopolitičkih ciljeva Druge Republike Poljske bilo neraskidivo povezano s aktivnostima poljskih diplomatskih odjela, posebno onih uspostavljenih u balkanskim državama. Poljski političari primijetili su važnost tih država kao mogućih saveznika poljske države u postizanju ciljeva strateškoga koncepta poljske vanjske politike.

Provodeći politiku približavanja balkanskim zemljama, diplomatski, vojni, trgovinski i kulturni odnosi uspostavljeni su prilično brzo, ali Poljska je posebnu pozornost posvetila savezništvu s Rumunjskom. Aksiom poljske vanjske politike na polju diplomacije i državne sigurnosti bila je potreba sklapanja strogoga savezničkog ugovora s Bukureštom. ${ }^{1}$ To međutim ne znači da druge zemlje ove regije nisu bile u orbiti interesa Poljske.

Političke i vojne vlasti bile su svjesne da je pred njima, ako žele održati vezu sa saveznicima, posebno onima iz zapadne Europe, izazov da razviju koncept strateških i tranzitnih putova koji bi Poljskoj omogućili održavanje komunikacije sa saveznicima. ${ }^{2}$ Ti koncepti predviđali su stvaranje koridora zahvaljujući kojima bi Poljska u slučaju sukoba s boljševičkom Rusijom (poslije Sovjetskim Savezom) ili Njemačkom ${ }^{3}$ mogla dobiti zapadnu pomoć.

Ti koridori, ili prema drugačijoj definiciji strateški putovi komunikacije „sjever-jug”, uz nesumnjive ekonomske, političke i vojne vrijednosti, trebali su

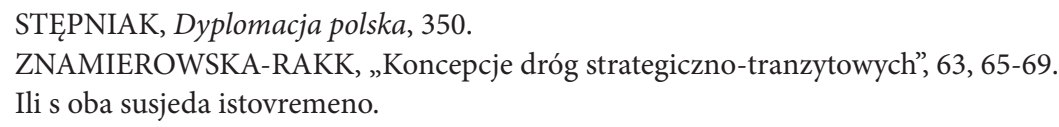


biti važan element koji povezuje poljsku državu i moguće saveznike u srednjoj Europi i na Balkanu.

Pored diplomatskih instrumenata, za provođenje tih koncepata Poljska je imala još jedan iznimno važan alat, a to je bila obavještajna služba smještena $u$ II. odjel Glavnoga stožera poljske vojske. Većina resursa i napora poljske obavještajne službe u opisanom razdoblju nesumnjivo je bila usmjerena na istok, ali interes II. odjel nisu bili samo susjedi Poljske nego i druge zemlje koje su imale ili mogle imati bilo kakvu važnost za sigurnost poljske države. Jedinica odgovorna za organiziranje informativnih aktivnosti na Balkanskom poluotoku bila je Referat $W$.

Glavni zadaci koje je obavljao Referat $W^{4}$ bili su prije svega:

- praćenje političke, ekonomske i vojne situacije u balkanskim zemljama

- praćenje promjena u oružanim snagama u pojedinim zemljama poluotoka

- pribavljanje informacija koje se odnose na organizaciju, opremu, naoružanje, mobilizaciju i ratne planove Kraljevine Srba, Hrvata i Slovenaca (SHS), Bugarske, Rumunjske te u manjoj mjeri Grčke i Turske

- razvijanje bijele emigracije i njezine aktivnosti u Bugarskoj i Jugoslaviji

- identificiranje i istraživanje komunističkih aktivnosti, Kominterne i boljševičkih obavještajnih službi u srednjoj Europi i na Balkanu.

Jedna od zemalja koju je poljska vojnoobavještajna agencija aktivno istraživala bila je Kraljevina SHS, formirana 1918. na ruševinama Habsburške Monarhije. ${ }^{5}$ Poput Republike Poljske, i ta je država svoju politiku u međuratnom razdoblju zasnivala na versailleskom sustavu, s pravom vjerujući da je on koristan za razvoj te zemlje koja se bori s brojnim unutarnjim i vanjskim problemima.

Održavanje najboljih mogućih odnosa s Kraljevinom SHS bilo je posebno važno za poljsku stranu. Vladajući krugovi Druge Republike Poljske nastojali su proširiti svoj utjecaj na jugoistočnu Europu. Jedan od koncepata poljske vanjske politike s početka dvadesetih godina pretpostavljao je i integraciju zemalja srednje i jugoistočne Europe. ${ }^{6}$

Porast utjecaja iz Čehoslovačke i posebno Njemačke u Jugoslaviji pratio se sa zabrinutošću. Pozorno su promatrane i aktivnosti jugoslavenskih, bugarskih,

\footnotetext{
4 Obavještajna služba na istoku, usmjerena prvenstveno protiv Sovjetskoga Saveza (do 1922. sovjetske Rusije), ali i protiv Litve i Čehoslovačke. Zanimala su ju i područja koja graniče sa Sovjetskim Savezom, Balkan te Bliski i Srednji istok. WOJTASZCZYK, Polskie Stużby Specjalne, 137; LARECKI, Wielki leksykon służb specjalnych świata, 451-455, 734.

$5 \quad$ Kraljevina Srba, Hrvata i Slovenaca nastala je 1. prosinca 1918. godine. BATOWSKI, Rozpad Austro-Wegier 1914-1918, 255-256.

6 KRZAK, „Attachat Wojskowy w Belgradzie”, 23.
} 
grčkih i rumunjskih komunista ${ }^{7}$ koji su, noseći vatru svjetske revolucije, formirali aktivne centre na Balkanskom poluotoku. Poljske vlasti također su zabrinuto gledale rastuću važnost (barem u prvoj polovini dvadesetih godina) ruske emigracije, osobito skupina povezanih s generalom Pjotrom Wrangelom, čije je glavno sjedište bila Kraljevina SHS. ${ }^{8}$ Osim toga u drugoj polovini dvadesetih godina „Dvojka” je zabilježila i niz podataka koji svjedoče o prodoru ukrajinskih nacionalista na teritorij Jugoslavije.

Sa zanimanjem se promatrao i razvoj oružanih snaga Jugoslavije, nešto manjih od poljske vojske. Jugoslavija je smatrana potencijalnim primateljem naoružanja i ratne tehnologije koju je proizvodila poljska industrija oružja te kao važan politički i vojni saveznik.

\section{Izvori i metode pribavljanja podataka o jugoslavenskoj vojsci}

Informacije o oružanim snagama Kraljevine SHS do sredine dvadesetih godina dobivale su se proučavanjem stručne literature i zahvaljujući intervjuima (razgovorima) akreditiranih poljskih diplomata (posebno atašea poljskoga veleposlanstva u Beogradu) pri jugoslavenskoj vladi. Informativni materijal dobiven u Beogradu potom se upućivao u Centralu u Varšavi, gdje se predavao Studijskom odjelu. ${ }^{10}$

Na temelju podataka prikupljenih u prvoj polovini dvadesetih godina pripremljen je grupni izvještaj koji je objavljen u internoj publikaciji u obliku obavještajne analize, tj. takozvanoga informativnog referata, a zatim i u informacijskim priopćenjima. Informativni referat sastavljao se u II. odjel Vrhovnoga zapovjedništva poljske vojske. Pripremao se svaka dva tjedna i sadržavao je sintezu trenutačnih političkih i političko-vojnih odnosa u srednjoj i jugoistočnoj Europi. Problematika tretirana u referatima odnosila se na pitanja međusobnih političkih odnosa i na promjene koje se događaju u organizaciji oružanih snaga balkanskih država i njihovih susjeda. Izneseni podaci sadržavali su i najvažnije informacije o događajima relevantnim za zemlju ili regiju, npr. o tijeku borbi u Grčko-turskom ratu ili borbi (incidentima) na jugoslavenskim granicama s Albanijom, Bugarskom i Mađarskom, kao i o pobunjeničkim aktivnostima u

\footnotetext{
7 Prema poljskim sigurnosnim službama, prikupljanje informacija o komunističkim pokretima bilo je usko povezano s prijetnjom koju je predstavljao Sovjetski Savez podržavajući tzv. svjetski komunistički pokret. Ustvari, Poljaci su znali da su se boljševičke specijalne službe infiltrirale u komunističke partije i za njih su bile jedan od najvažnijih izvora informacija. Više o infiltriranju u komunističke pokrete i njihovoj povezanosti s boljševicima može se naći u djelima Andrzeja Pepłońskog, Piotra Kołakowskog i autora ovoga članka.

$8 \quad$ KRZAK, Czerwoni Azefowie, 62-71.

9 Kolokvijalni naziv za poljske obavještajne službe, točnije za II. odjel u međuraću.

10 ŁOSSOWSKI, Dyplomacja polska, 102.
} 
Makedoniji i Crnoj Gori. Veliki dio materijala bio je posvećen talijanskoj ekspanziji na Balkanu i umiješanosti talijanskih nacionalista i vladinih krugova u riječki slučaj.

U dijelu posvećenom vojnim pitanjima pisalo se, među ostalim, o jugoslavenskoj reorganizaciji i prelasku oružanih snaga Kraljevine SHS iz ratnoga u mirnodopsko stanje. ${ }^{11}$ Ti su podaci dosta precizno prikazali promjene u zapovjedništvima Vojske Kraljevine SHS, posebno u ministarstvu i Generalštabu.

Nakon obrade informativni materijali prosljeđivali su se Ministarstvu vojnih poslova i načelniku Glavnoga stožera. Ponekad su slani i premijeru i ministru vanjskih poslova. Neki materijali poslani su i jedinicama političke policije (Politička obrana), posebno oni s podacima vezanim za aktivnosti ukrajinskih nacionalista, komunista i boljševičkih specijalnih službi.

Treba zaključiti da je većina informativnoga materijala koji se odnosio na vojne poslove Jugoslavije do kraja dvadesetih godina potjecao iz tzv. bijele obavještajne službe.

Osim proučavanjem tiska i stručnih publikacija te opažanjem, poljski vojni diplomati dobivali su informacije iz službenih odnosa s osobljem vojnih postrojbi i institucija zemlje domaćina, kao i predstavnicima lokalnoga društva. Sudjelovali su i u vojnim demonstracijama i manevrima, koji su omogućili provjeru prethodno dobivenih informacija. Posebno mjesto u sistemu prikupljanja podataka o političkoj i vojnoj situaciji države akreditacije i njezinim oružanim snagama zauzimala je suradnja s vojnim atašeima savezničkih i prijateljskih zemalja, s kojima su razmjenjivane vojne i političke informacije.

Ataše je pripremao mjesečne izvještaje i dnevne informacije. Dostavljao je i druge materijale ${ }^{12} \mathrm{u}$ skladu s naredbama načelnika II. odjela ili načelnika Generalštaba poljske vojske. Godine 1935. uvedena je evidencija inozemnih vojski. ${ }^{13}$ Prema preporukama načelnika II. odjela, svaki ataše trebao je stvoriti tajni dosje dokumenata u kojima su prikupljani podaci o višem zapovjedničkom osoblju u skladu s obrascem poslanim iz obavještajne centrale (tj. II. obavještajnog odjela). Dosjei su morali biti pravilno osigurani i nitko nije smio nikome odati informacije ili podatke iz njih (iznimka je bio šef II. odjela). Ažurirane podatke o rukovodstvu i višem zapovjedništvu stranih vojski trebalo je poslati u evidencijski

\footnotetext{
11 CAW, Oddz. II SG, sygn. I.303.4.7173, Referat Informacyjny z 1 maja 1920 r., Referat Informacyjny z 1 lipca 1920 r., Referat Informacyjny z 15 lipca 1920 r., Referat Informacyjny z 15 września 1920 r., Referat Informacyjny z 1 sierpnia 1920 r.

12 Izvješća i informacije o aktualnim događajima koji su utjecali na međusobne kontakte Poljske i zemlje boravka diplomata, a ticali su se relevantnih događaja vezanih za unutarnju i vanjsku situaciju zemlje boravka.

13 AAN, AW, sygn. AII/15, t. 2. Ewidencja personalna armij obcych, nr L. 6853/II.S.O.T.O z 07.08.1934 r.
} 
registar Generalštaba. Pored toga atašei su bili obvezni kupovati vojni i politički tisak i stručna izdanja, koje su potom slali u zemlju.

Informacije o funkcioniranju jugoslavenske vojske i njezina obrambenoga sustava stizale su i iz drugih diplomatskih ustanova u jugoistočnoj Europi. Jugoslavenskim pitanjima bavili su se i vojni atašei Republike Poljske akreditirani u Rumunjskoj, Italiji, Mađarskoj i Turskoj. Druga skupina informativnoga materijala stizala je preko razmjene II. odjela sa štabovima prijateljskih ili savezničkih zemalja.

Još jedan izvor podataka bila su politička izvješća izaslanstava, koja su se osim političkim i ekonomskim bavila i pitanjima koja se odnose na oružane snage. Civilni diplomati, obično s vlastitim izvorima informacija, ali i izvrsnim uvidom, često su prikupljali vrijedne podatke o trendovima razvoja i promjenama osoblja u okviru oružanih snaga. Posebno vrijedni podaci tiču se karakteristika pojedinaca iz visokoga zapovjedničkoga kadra jugoslavenske vojske.

Od ranih tridesetih godina obavještajne informacije primane su iz obavještajnih jedinica koje su funkcionirale u Turskoj, Rumunjskoj i Italiji. Iz dokumenata koji se nalaze u Središnjem vojnom arhivu proizlazi da je u prvoj polovini dvadesetih godina u Beogradu funkcionirala jedinica obavještajne službe E.8, koja se međutim nije bavila prikupljanjem podataka o oružanim snagama Jugoslavije, nego je prodirala u krugove ruske emigracije, a posebno grupacije povezane s monarhistima, pristašama Lijevih socijalističkih revoluciona, kao i krugove grupirane oko generala P. Wrangela. ${ }^{14}$

Najveća i istovremeno najzanimljivija skupina podataka o oružanim snagama Kraljevine Jugoslavije počela je pristizati početkom tridesetih godina preko operativnih (obavještajnih) izvora. Praktično do 1937. Centrala poljske obavještajne službe posjedovala je niz zanimljivih podataka o političkim i organizacijskim promjenama u jugoslavenskoj vojsci i vojnom potencijalu te zemlje. Osnovni izvor tih podataka bilo je izaslanstvo pod kriptonimom Anitra, smješteno u Turskoj.

Anitra je osnovana 1932. u Ankari. Njome je upravljao Karol Dubicz-Penther, savjetnik izaslanstva, a potom i veleposlanstva. Usporedno je postojala obavještajna ustanova čija je šifra bila Ghazi, osnovana u listopadu 1933. u Generalnom konzulatu u Istanbulu. U rujnu 1936. premještena je u poljsko izaslanstvo u Ankari. Njome je sve do rujna 1937. upravljao kapetan konjice Jerzy Litewski, a nakon njega do 1939. - kao Ghazi II - kapetan Wiktor Zaleski. ${ }^{15}$ Obje institucije uglavnom su se bavile istraživanjem Sovjetskoga Saveza, no zanimali su ih

14 CAW, Oddz. II SG, sygn. I.303.4.70, Program prac Ref. B/3-4 za czas od 20.VIII.1923 r. do dnia 31.XII.1923 r.

15 KOŁAKOWSKI, Czas próby, 217. 
i Balkan, Bliski istok i srednja Azija. Među informatorima su bili Rusi, Turci i predstavnici kavkaskih naroda. Anitrin glavni izvor informacija bili su zaposlenici i časnici turskoga Generalštaba.

Iz sačuvanih materijala koji se tiču Balkana bar nekoliko desetaka izvještaja, analiza, depeša, pregleda informacija i studija nastalih od 1932. do 1937. odnosi se na Jugoslaviju i njezine oružane snage. Preostali tematski opisuju pitanja koja se odnose na ostale vojske Balkanskoga poluotoka.

Informativni materijal sadržava pojedinačne (tematske) ili kolektivne studije koje opisuju organizaciju, stvaranje novih jedinica, obuku, opremu i vojnu politiku Jugoslavije u različitim godinama. Pripremljen je u obliku izvještaja ili informacija i prosječno ima 3-4 tipkane stranice. Velika većina materijala ima dokumentarni karakter, a samo neki izvještaji sadržavaju procjene, prognoze ili zaključke.

U Centralu su pristizali i podaci dobiveni od bečkoga ureda atašea, npr. pismo od 20. lipnja 1921. u kojem načelnik II. odjela pukovnik Ignacy Matuszewski nalaže atašeu da dopuni podatke o jugoslavenskoj vojsci, šaljući ujedno izvještaje koje je pripremilo diplomatsko izaslanstvo u Beču. Prema tim podacima, sredinom 1921. Vojska Kraljevine SHS bila je podijeljena na devet teritorijalnih okruga. Svaki okrug trebao je obuhvaćati po jednu pješadijsku diviziju. Jedina iznimka bio je VI. okrug, u kojem su bile raspoređene dvije pješadijske divizije. Prvi okrug obuhvaćao je Krajinu i zapadni dio Hrvatske zajedno s Rijekom; u II. okrug spadala je Hrvatska, zapadni dio Bosne i Lika; III. okrugu pripadao je zapadni dio Slavonije; IV. okrug obuhvaćao je istočni dio Slavonije i Bačku; V. okrug formiran je na istočnom teritoriju Bosne i Hercegovine; sjeverna Srbija i južni Srijem bili su uključeni u VI. okrug; južna Srbija i Makedonija dodijeljene su VII. okrugu; VIII. okrug činio je ostatak Srbije, a IX. okrug obuhvatio je teritorij Crne Gore. ${ }^{16}$

Prema izvještaju iz Beča, svaka pješadijska divizija trebala je imati dvije brigade s po četiri puka, a na svaka dva puka bio je jedan rezervni bataljon. Puk je trebao imati četiri bataljona, a bataljon četiri čete. Jedna četa imala je oko 160 vojnika, od kojih su $50 \%$ bili veterani, a ostatak poslijeratni regruti. ${ }^{17}$

Pored toga svaka pješadijska divizija trebala je imati konjički divizion ili eskadrilu, dva artiljerijska puka i jedan željeznički puk. Svaka brigada trebala je imati dva pionirska bataljona, dvije čete mitraljeza i jednu reflektorsku četu. U svakoj pješadijskoj diviziji trebalo je formirati zrakoplovnu jedinicu. ${ }^{18}$

\footnotetext{
16 AAN, AW, sygn. AII/3, Pismo do Attaché Wojskowego P.P. w Belgradzie z 20 czerwca 1921 r., Rozkaz Nr 2.

17 Isto.

18 Isto.
} 
Glavno središte za prikupljanje podataka o vojnim pitanjima Jugoslavije bio je Ured vojnoga atašea Republike Poljske smješten pri poljskom veleposlanstvu u Beogradu. Diplomatska misija u Beogradu osnovana je u prosincu 1918., njezin prvi chargé d'affaires postao je Czesław Pruszyński, a prvi vojni predstavnik Republike Poljske u Kraljevini SHS bio je potpukovnik Franciszek Kopeczny, koji je stigao u Zagreb 10. studenog 1918. godine. U početku je bio zapovjednik sabirne stanice, a od 3. siječnja 1919. vojni punomoćnik. ${ }^{19}$ Vojni ministar Kraljevine SHS general Mihailo Rašić uvjeravao ga je tijekom primanja poljskoga predstavnika da će mu pružiti svu potrebnu pomoć. ${ }^{20} \mathrm{U}$ skladu s naredbom načelnika Generalštaba br. 06679 od 31. prosinca 1918., potpukovnik F. Kopeczny u početku je bio službeno podređen vojnom predstavniku u Beču generalu Adamu Nowotnyju, preko kojega je trebao slati dokumente u zemlju.

Od ožujka 1919. promijenila se podređenost vojnoga poslanstva u Kraljevini SHS, kojim je počelo rukovoditi VI. odjel Generalštaba Vojske Republike Poljske. Informativni rad predstavništva u prvim mjesecima poslovanja u Zagrebu sastojao se uglavnom od analize tekućega tiska ${ }^{21}$ i slanja izvještaja u zemlju. Sadržaj izvještaja bio je podijeljen na tri područja - vojna, unutarnja i vanjska pitanja. ${ }^{22}$ Glavni zadatak vojnih diplomata u razmotrenom razdoblju bio je nabavljati oružje i streljivo austrougarske vojske zaostalo na teritoriju Srbije. Poljski diplomati aktivirali su se i u prikupljanju oružja iz skladišta trupa Antante u Solunu.

U prosincu je poljski predstavnik dao niz informacija u vezi s reorganizacijom oružanih snaga Kraljevine SHS. Prema tim podacima, jugoslavenska je vojska u sklopu reorganizacije odabrala nove vojnike, istovremeno otpuštajući one mobilizirane tijekom rata, čime se oslobodila vojnika čija je motivacija nakon završetka vojnih operacija u potpunosti nestala. U referatu iz prosinca 1919. posebna pozornost posvećena je primanju u službu nekolicine generala slovenske i hrvatske nacionalnosti, što je prema mišljenju vojnih diplomata i

\footnotetext{
19 Potpukovnik F. Kopeczny nije imao klasičnu funkciju vojnoga atašea, no predstavljao je poljske vojne vlasti. Glavni zadatak bio mu je bavljenje pitanjima poljskih ratnih zarobljenika, pripadnika bivše austrougarske vojske, i pribavljanje oružja i vojne opreme za obnovljenu poljsku vojsku. Stoga mu je sjedište bio Zagreb, a ne Beograd. Pored toga, poljska misija u obrađenom razdoblju bila je u fazi organizacije, a sama diplomatska misija sastojala se od dva diplomata. Nakon završetka organizacijskoga rada i uspostave Ureda atašea, vojno-diplomatska misija premještena je 20. lipnja 1919. u Beograd.

20 AAN, AW, sygn. AII/5/1, 59-70. Raport Pełnomocnika Wojskowego Państwa Polskiego w Królestwie SHS z 23 stycznia 1919 r.; STĘPNIAK, Dyplomacja polska, 57.

21 AAN, AW, sygn. AII/5/1, 534-54, „Agramer”, „Tagblatt”, „Obzor”, „Riječ”, „Pravda”, „Radničke novine".

22 AAN, AW, sygn. AII/5/1, 412-415. Raport prasowy nr L. 72 z dnia 1 kwietnia 1919 r. U jednom od izvješća između 16. i 31. ožujka 1919. potpukovnik F. Kopeczny informirao je o reorganizaciji trupa u Sloveniji i Hrvatskoj, gdje su postojeći vojni okruzi i dopunska zapovjedništva te nacionalne obrambene komande zamijenjeni pukovskim okružnim komandama.
} 
analitičara iz II. odjela trebalo naznačiti pokušaje konsolidacije višenacionalne jugoslavenske vojske. ${ }^{23}$

Prvi vojni ataše Republike Poljske u Kraljevini SHS bio je major/potpukovnik Aleksander Powroźnicki, ${ }^{24}$ koji je započeo misiju 10. lipnja 1919. godine. ${ }^{25} \mathrm{U}$ početku je službovao u Zagrebu, a od 20. lipnja 1919., nakon preseljenja Ureda u glavni grad Kraljevine, obavljao je dužnosti u Beogradu. ${ }^{26}$

Godina 1920. obiluje brojnim zanimljivim podacima o vojnom stanju u prigraničnom pojasu i daljnjoj reorganizaciji oružanih snaga Jugoslavije. U informativnom referatu od 1. siječnja 1920. stoji da je Jugoslavija zbog napetih odnosa s Albanijom, Mađarskom, Italijom i Bugarskom nastavila držati određeni broj jedinica u pograničnom pojasu. Istovremeno je tijekom opisanoga razdoblja većina snaga Kraljevine SHS bila usmjerena na granicu s Italijom zbog incidenata nacionalističkih skupina povezanih s Gabrieleom D'Annunzijem. Početkom 1920. na mađarskoj granici zabilježeni su brojni incidenti, koji su se često pretvarali u oružane čarke. Prema Uredu atašea, male snage koje je Jugoslavija mogla upotrijebiti za zaštitu granice s Mađarskom bile su glavni razlog pohoda mađarskih paravojnih trupa. ${ }^{27}$

Prema informativnom referatu od 1. veljače 1920., zbog složene situacije Kraljevina SHS nastavila je držati znatne vojne snage u pograničnom pojasu s Mađarskom, Albanijom, Italijom i Bugarskom. U istoj analizi prijavljeno je i neprestano preustrojavanje kraljevske vojske. Prema tim podacima, oružane snage Kraljevine sastojale su se od pet armija: I. armije sa zapovjedništvom u Novom Sadu, II. armije u Sarajevu, III. armije u Skopju, IV. armije u Zagrebu i V. armije, koja je bila u procesu formiranja, a zapovjedništvo joj je trebalo biti u Trebinju. ${ }^{28}$ Vojska je imala preko 200000 vojnika. Prema izvještaju, jugoslavenska vojska trebala je u mirnodopsko vrijeme imati oko 75000 oficira i vojnika, koji su služili u 65 pukova. ${ }^{29}$ Predstavljen je i opći prikaz mobilizacijskoga sustava Kraljevine, prema kojem su svi muškarci u dobi od 18 do 52 godine bili obvezni služiti u vojsci, a bili su podijeljeni u tri skupine (klase ili zvanja), tj. prvo regrutiranje odnosilo se na muškarce u dobi od 18 do 32 godine, drugo

CAW, Oddz. II SG, sygn. I.303.4.7173, Referat Informacyjny z 15 grudnia 1919 r.

STAWECKI, „Attaché Wojskowi”, 126.

AAN, AW, sygn. AII/3, Notatka z pamiętnika ppłk Aleksandra Powroźnickiego, nr $4 \mathrm{z}$ 18.02.1921 r. Kao što proizlazi iz bilješki potpukovnika A. Powroźnickog, diplomatske dužnosti predao mu je potpukovnik F. Kopeczny. Ipak, u dosad istraženim izvornim materijalima nisu pronađeni dokazi koji bi upućivali na to da je Kopeczny službeno držao položaj vojnoga atašea Republike Poljske.

26 Isto.

27 CAW, Oddz. II SG, sygn. I.303.4.7173, Referat Informacyjny z 1 stycznia 1920 r.

28 Ove podatke potvrdio je i dr. Mile Bjelajac iz Instituta za noviju istoriju Srbije; BJELAJAC, Vojska Kraljevine SHS, 12.

29 CAW, Oddz. II SG, sygn. I.303.4.7173, Referat Informacyjny z 1 lutego 1920 r. 
na one od 32 do 45 godina, a treće na muškarce od 45 do 52 godine. Izvještaj je procijenio da je kraljevska vojska dobro uniformirana i da ima dovoljno oružja i streljiva. Međutim, nedostajalo je vojarni, posebno u Srbiji, gdje su ih najviše uništile njemačke i austrougarske okupacijske snage. ${ }^{30} \mathrm{U}$ sljedećem referatu od 1. ožujka objavljeno je da se kraljevska vojska dodatno smanjila jer je u roku od mjesec dana od 18 divizija ostalo $16,{ }^{31}$ koje su ulazile u sustav četiriju armija, čineći privremene armijske okruge (oblasti). ${ }^{32}$

Potpukovnik A. Powroźnicki i njegov nasljednik kapetan Józef Pędracki³, koji je tu dužnost preuzeo 1921., ${ }^{34}$ slali su brojne podatke o promjenama u naoružanju i organizacijskoj strukturi Vojske Kraljevine SHS ${ }^{35}$ te političkoj i ekonomskoj situaciji u jugoslavenskoj državi. Osim toga J. Pędracki izvještavao je Glavni stožer u Varšavi o nizu vojnih sporazuma zaključenih između Kraljevine SHS i Rumunjske i Čehoslovačke, koji su stvorili Malu Antantu. ${ }^{36} \mathrm{U}$ poruci iz svibnja 1921. upućenoj Varšavi ocijenio je da Jugoslavija razmatra vojne akcije protiv Bugarske i Mađarske. ${ }^{37}$

\begin{tabular}{ll}
\hline 30 & Isto. \\
31 & BJELAJAC, Vojska Kraljevine SHS, 12. \\
32 & CAW, Oddz. II SG, sygn. I.303.4.7173, Referat Informacyjny z 1 marca 1920 r. \\
33 & Józef Pędracki rođen je 17. kolovoza 1891. u gradu Hołowecko (Mala Poljska). Završio je
\end{tabular} osam razreda srednje škole. Sa srednjoškolskom diplomom 1. listopada 1911. pozvan na vojnu službu u austrijsku vojsku te pohađa tečaj u školi za časnike topničkih rezervi u Sarajevu. Od 1912. do 1914. studira pravo na sveučilištima u Beču i Krakovu. U srpnju 1914. pozvan na aktivnu službu u austrijskoj vojsci i poslan na frontu, gdje je promaknut u čin poručnika. Kao obavještajni časnik, a zatim zapovjednik baterije, sudjelovao u borbama na talijanskoj, srpskoj i albanskoj fronti. Dana 30. listopada 1918. pridružio se poljskoj vojsci, gdje je postavljen za zapovjednika općinske vojne policije u Oświęcimu. U veljači 1919. poslan u Kraljevinu SHS kao pomoć poljskom vojnom predstavniku, a zatim je nakon dva mjeseca (svibanj 1919.) postao pomoćnik vojnoga atašea u poljskoj misiji u Beogradu. Nakon povratka u zemlju u ožujku 1920. raspoređen na rad u II. odjel Vrhovnoga zapovjedništva poljske vojske. Dana 1. siječnja 1921. vratio se u Beograd, gdje je postao šef vojne diplomatske misije. Nakon nekoliko mjeseci u inozemstvu vratio se u zemlju, gdje je 1. studenog 1921. postavljen na mjesto šefa Prvog sektora II Odjela Vrhovnoga zapovjedništva poljske vojske. Od 1. travnja do 30. rujna 1924. na školovanju za zapovjednika eskadrile u Poznańu, gdje je u međuvremenu (13. kolovoza) promaknut u čin majora. Po završetku tečaja postaje zapovjednik eskadrile u 23. poljskoj topničkoj pukovniji, nakon čega je 17. rujna 1926. premješten u časničku pješačku školu na mjesto instruktora topništva. Potom 18. srpnja 1929. preuzima dužnost pomoćnika intendanta u 18. terenskoj topničkoj pukovniji, a posljednjega dana 1929. je umirovljen. AAN, AW, sygn. AII/4/1, k. 338, Karta osobowa por. J. Pędrackiego; CAW, KAP, sygn. 1769/89/3914, Józef Pędracki.

34 STAWECKI, „Attaché Wojskowi”, 130.

35 AAN, AW, sygn. AII/6, Raport nr 59/Pf z 19.03.1921 r. dotyczący sytuacji politycznej i wojskowej SHS. Među ostalim, izvještavalo se o promjenama na položaju načelnika Generalštaba Kraljevine SHS, koji je trebao pripasti generalu Petru Pešiću, kao i o poboljšanju opskrbe oružjem i uniformama za vojsku, reorganizaciji kopnenih snaga i prebacivanju kraljevskoj mornarici brodova iz bivše mornarice Austro-Ugarske.

36 KOŁAKOWSKI, Między Warszawą a Pragą, 32.

37 CAW, Oddz. II SG, sygn. I.303.4.7616, Depesza z Belgradu z 17/V.1921 r. 
Ured atašea u Beogradu likvidiran je u veljači 1922., ali kapetan Stefan Michalski ${ }^{38}$, imenovan još 1921. za vojnoga atašea, neslužbeno je zadržao tu funkciju do 1924. godine. ${ }^{39}$ To mu je omogućilo kontinuitet rada i održavanje kontakata koji su u tim uvjetima bili vrlo važni i kretao se u okruženju viših oficira Generalštaba kraljevske vojske i u krugovima diplomatskoga zbora. Zadatke beogradskoga atašea trebalo je preuzeti veleposlanstvo u Budimpešti, ali zapravo se to nikada nije dogodilo. Šef II. odjela i veleposlanik u Budimpešti usprotivio se tom rješenju jer je smatrao da Poljska treba imati ured atašea u Kraljevini SHS zbog „širenja oružanih snaga SHS-a”. ${ }^{40}$

Unatoč brojnim poteškoćama, kapetan S. Michalski nastavio je svoju aktivnost šaljući mnogo zanimljivih podataka o organizaciji oružanih snaga Kraljevine SHS. ${ }^{41} \mathrm{U}$ veljači je sastavio opsežnu analizu organizacije kraljevske vojske. Izvijestio je da se jugoslavenska pješadijska divizija sastojala od artiljerijske brigade sačinjene od dva puka. Puk je imao dvije do tri eskadrile, ${ }^{42} \mathrm{~s}$ iznimkom pješadijskih divizija Jadran i Zeta, koje su obuhvaćale pukove s (3.) brdskom divizijom. ${ }^{43}$ Opisao je i ustrojstvo artiljerije na razini vojske i Vrhovne komande. Posebnu skupinu informativnoga materijala činile su studije vezane za probleme odnosa balkanskih država (uključujući Kraljevinu SHS) s Čehoslovačkom, Njemačkom i Italijom. Čehoslovačka je imala posebno mjesto u izvještajima diplomata zbog uloge koju je južni susjed Republike Poljske odigrao u vanjskoj politici Varšave. Bilo je važno imati pouzdane podatke o djelovanju Praga na međunarodnoj sceni, posebno na Balkanu. Treba podsjetiti da je neprijateljski

38 Stefan Michalski rođen je 29. travnja 1890. u Varšavi. Od 1904. aktivno sudjelovao u tajnoj organizaciji samoobrazovanja mladih u Realnoj školi u Varšavi. Tijekom 1905./06. član omladinskoga udruženja PPS. Zbog sudjelovanja u štrajku 1905. izbačen iz Realne škole, nakon čega je počeo studirati u školi Emiliana Konopczyńskog. Od 1908. do 1912. studirao filozofiju u Zürichu i Münchenu. Potom počeo studirati pravo na Moskovskom sveučilištu, gdje je 1915 . dobio diplomu. Od 1. studenog 1915. služi u ruskoj vojsci, započevši službu u topničkoj školi. U kolovozu 1917. počeo služiti u Prvom poljskom korpusu. Dana 23. studenog 1918. pridružio se obnovljenoj poljskoj vojsci, gdje je postavljen za šefa Odjeljenja IId, VI. odjela Generalštaba poljske vojske. Godine 1919. postavljen za zamjenika šefa misije pri zapovjedniku oružanih snaga na jugu Rusije u Taganrogu. Nakon poraza vojske generala Denikina premješten u Sevastopolj, gdje je do studenoga 1920. zastupao poljske interese u vojsci generala Wrangela. Dana 1. studenog 1921. imenovan vojnim atašeom u poljskoj misiji u Beogradu. Nakon povratka u Poljsku 1923. poslan na rad u II. odjel Generalštaba. Godine 1925. završio vojnu službu i premješten na posao u Ministarstvo riznice, gdje je preuzeo mjesto ministarskoga savjetnika. Od 1930. do 1932. financijski savjetnik u poljskom veleposlanstvu u Parizu. Po povratku u zemlju radi u Nacionalnoj poljskoj banci, gdje obavlja dužnosti voditelja Gospodarskoga ureda. CAW, KAP, sygn. 1769/89/3406, Michalski Stefan.

39 STAWECKI, „Attaché Wojskowi”, 126.

40 AAN, AW, RP, sygn. AII/6, Informacja o likwidacji stanowiska Attaché z 19 lutego 1922 r.

41 CAW, Oddz. II SG, sygn. I.303.4.7077, Raport Attaché w Belgradzie nr L. 124 z 28 lutego 1924 r., Artylerja wojska SHS.

42 Nakon mobilizacije pješadijska divizija trebala je imati 18 baterija i 72 topa. Isto.

43 Isto. 
stav prema Poljskoj ključnih čeških političara, Tomáša Masaryka, Edvarda Beneša i drugih, morao izazvati zabrinutost Varšave ${ }^{44}$ i dovesti do povećanih obavještajnih aktivnosti usmjerenih protiv južnoga susjeda Poljske unatoč naporima Francuske i Rumunjske da Varšavu povežu s Malom Antantom, a samim time i Čehoslovačkom. ${ }^{45}$

Dakle, djelatnost Jugoslavije kao dijela Male Antante ${ }^{46}$ postala je predmet najmanje desetak informacija koje je poljski diplomat uputio II. odjelu i Ministarstvu vanjskih poslova. Izvještavao je uz ostalo o vojnoj i političkoj situaciji u Bugarskoj ${ }^{47}$ i o tijeku i rezultatima Vojne konvencije održane sredinom rujna 1923. u Pragu. ${ }^{48}$ Prema atašeovoj procjeni, češki političari težili su uspostavljanju jedinstvenoga zapovjedništva spojenih oružanih snaga Male Antante i kodifikaciji naoružanja u savezničkim vojskama. Ujedinjene oružane snage trebale su dovesti do ravnoteže snaga u odnosu s mađarskom vojskom. Diplomat je također upozorio na rastući utjecaj Čehoslovačke među državama srednje i istočne Europe, što je nedvojbeno ugrožavalo interese i položaj Poljske.

Stefan Michalski obavijestio je u porukama upućenim II. odjelu i o bilateralnim sporazumima i odnosima između Kraljevine SHS i Grčke, Turske, Rumunjske i Bugarske. ${ }^{49}$ Pravilno je ocijenio da je vanjska politika Kraljevine SHS usmjerena na izgradnju sporazuma sa susjedima koji su trebali osigurati nepovredivost njezinih granica. ${ }^{50}$

Iznimno važan dokument koji je pripremio kapetan Michalski izvještaj je u kojem je sažeo aktivnosti vezane za nekoliko tjedana 1923., u kojem je napisao da je uspio pribaviti niz zanimljivih podataka o Vojsci Kraljevine SHS, koja je jedan od „najvažnijih čimbenika” na Balkanu. Poljski diplomat ocijenio je da su oružane snage Kraljevine SHS jedan od najvažnijih elemenata državnoga obrambenog sustava, a zbog svojega potencijala i vrlo važan igrač u slože-

\section{WANDYCZ, Z dziejów dyplomacji, 130, 137-140.}

KOŁAKOWSKI, Między Warszawa a Praga, 35-36.

46 Sustav političkih i vojnih saveza triju zemalja, Čehoslovačke, Rumunjske i Kraljevine SHS, usmjeren prvenstveno protiv Mađarske i Austrije. Glavni tvorac sporazuma bio je češki političar Edvard Beneš. Koalicija se temeljila na bilateralnim ugovorima koje su 1920./21. potpisali predstavnici spomenutih država. Sporazumi su dopunjavani konvencijama i više puta ratificirani. Mala Antanta postojala je do 1939. godine. BATOWSKI, Między dwiema wojnami 1919-1939, 137-143; LECZYK, Polska i sasiedzi, 69.

47 AAN, AW, sygn. AII/20, t. 1. Raport Polityczny nr 219 z 25 lipca 1923 r. Informacja: „Mała Ententa" wobec przewrotu w Bułgarii.

48 AAN, AW, sygn. AII/20, t. 1. Informacja Attaché Wojskowego z 17 września 1923 r.

49 CAW, Oddz. II SG, sygn. I.303.4.7627, Stosunki bułgarsko-serbskie-czeskie z Rumunją, Attaché Wojskowy przy Poselstwie Polskim w Bukareszcie, I.252/23 z 5 maja 1923 r. Slične informacije dolazile su i iz drugih ureda atašea, npr. iz Bukurešta.

50 AAN, AW, sygn. AII/20, t. 1. Informacja nr 122721/II Inf.IID.1 z 19 czerwca 1923 r. dotyczy Umowy Salonickiej. 
nim međunarodnim odnosima u opisanom razdoblju. ${ }^{51}$ Godine 1924. poslao je i opsežan izvještaj o ustrojstvu, dislokaciji, zadacima i opremi pograničnih trupa. Te su se informacije odnosile na prvu fazu organizacije sistema zaštite granica Kraljevine, ${ }^{52} \mathrm{u}$ okviru koje su formirane stražarske kule, satnije, odredi na granicama s Bugarskom, Grčkom i Albanijom. ${ }^{53}$ Michalski je izvještavao i o zapovjednoj strukturi i o tome da su zaštitu albanske granice preuzeli ruski dobrovoljci. Istovremeno je napisao da granične trupe imaju znatne probleme zbog nedostatka oficira, posebno mlađih oficira u vodovima i četama.

Nakon razrješenja Michalskog i neimenovanja novoga atašea, dužnosti vojnoga diplomata obavljao je poljski veleposlanik Zdzisław Okęcki, koji je u informacijama od 12. siječnja 1925. izvijestio da se jugoslavenska vojska sastoji od četiri armije, u čijem je sastavu bilo 16 pješadijskih divizija (po četiri u svakoj armiji). Također je obavijestio da su oružane snage Kraljevine u procesu reorganizacije jer je u okviru pojedinih divizija bilo predviđeno smanjenje broja bataljona, od kojih je bilo planirano stvaranje novih taktičkih grupacija (divizija). Osim toga zastupnik je izvijestio da su streljačke čete povećane sa 125 na 185 vojnika. Pukovi su trebali imati oko 4000 vojnika. ${ }^{54}$ Opisao je vojno-političku situaciju na teritoriju jugoslavenske države početkom 1925., spominjući koncentraciju znatnih snaga u Makedoniji. To je, prema njegovu mišljenju, izraz pokazivanja snage i odlučne borbe protiv aktivnosti makedonskih i albanskih bandi na tom području države. ${ }^{55}$

Diplomat je i vrlo precizno okarakterizirao duh i nacionalnu situaciju kraljevske vojske. Javio je da su vojnici koji služe u jedinicama pomiješani i ne postoje nacionalno ujednačeni pukovi. Hrvatski i slovenski elementi najčešće su se miješali sa srpskim. „[...] Srbi pomiješani s Hrvatima služe u pukovima. Mnogi Hrvati služe u Makedoniji. Unatoč predizbornoj političkoj agitaciji u cijeloj zemlji i srpsko-hrvatskim poteškoćama, među vojnicima obaju slavenskih plemena postoje dobri odnosi i nema nacionalnih trvenja." ${ }^{56}$ Srbi su prevladavali u oficirskom korpusu. Prema njegovim podacima, časnici Hrvati, koji su potjecali iz austrougarske vojske, nisu se mogli prilagoditi službi u novim uvjetima. Međutim, te podatke treba promatrati s oprezom jer su njihov izvor bili oficiri kraljevskoga

51 CAW, Oddz. II SG, sygn. I.303.4.51, Raport Attache Wojskowego przy Poselstwie Polskim w Belgradzie z stycznia $1923 \mathrm{r}$.

52 CAW, Oddz. II SG, sygn. I.303.4.7077, Informacija dot. wojsk granicznych Jugosławii/Król. SHS. Pismo Attaché Wojskowego RP nr 132/24 z 08.03.1924 r.

53 Zaštitu granica s Mađarskom, Austrijom i Italijom preuzele su pogranične trupe 1926. nakon formiranja dodatnih četa. BJELAJAC, Vojska Kraljevine SHS, 38.

54 CAW, Oddz. II SG, sygn. I.303.4.7077, Reorganizacja i duch jugosłowiańskiej armii.

55 Isto, 2. Citirano izvješće glasi: „[...] Koncentracija vojnih snaga u Makedoniji dokazuje da nema bojazni za Hrvatsku. To je bila posljedica potrebe da se zaštite od makedonsko-albanskih bandi i pokažu snagu susjedima [...]."

56 Isto. 
Generalštaba (Srbi), zbog čega ih je teško smatrati pouzdanima. Razloge takva stava Hrvata možemo potražiti u nejednakom postupanju s tim dijelom stručnoga kadra stožera oružanih snaga. Osim toga zastupnik je ocijenio stanje proširenja utvrđenja Boka kotorska i zadatke flote Kraljevine SHS, koja bi se, prema njegovim riječima, mogla uspješno suočiti s Italijom. ${ }^{57}$ Ta se procjena međutim ne čini točnom jer je mornarica Kraljevine Italije u opisanom razdoblju imala veliki borbeni potencijal i ratno iskustvo stečeno u borbama s austrougarskom i njemačkom flotom na Jadranu tijekom Velikoga rata.

Godine 1925. poslanstvo je ponovno aktivirano imenovanjem vojnoga atašea, majora Stanisława Grodzkog ${ }^{58}$, koji je na toj funkciji bio do 1929. godine. ${ }^{59}$ Ponovno formiranje poslanstva u Beogradu motivirano je potrebom da se započne rad na konvenciji o tranzitu, ${ }^{60}$ koja je u svjetlu poljskih ratnih planova bila od temeljne važnosti za sigurnost Druge Republike Poljske. ${ }^{61}$ Prema arhivskim dokumentima, Francuska - također saveznik Poljske - pozvala je Poljsku

\footnotetext{
57 Isto, 3.

58 Stanisław Edward Grodzki rođen je 10. listopada 1892. u Grodnu. Po završetku realne srednje škole u Pinsku studirao je na Školi političkih znanosti u Varšavi. Nakon izbijanja Prvoga svjetskog rata preseljen u rusku vojsku, gdje je završio vojnu školu u Vilniusu (1914.) i tečaj za zapovjednika čete u Saint-Cyru u Francuskoj (1915.). Od 1915. do 1917. služi u 11. pješačkoj pukovniji kao zapovjednik čete i bataljuna. Potom je poslan u Francusku za pomoćnika ruskoga vojnog atašea. U Francuskoj je bio i zapovjednik logora pobunjeničkih ruskih vojnika iz 1. i 3. brigade. Nakon likvidacije logora 1917. pridružio se poljskoj vojsci u Francuskoj, uz istodobnu zadaću u francusko-poljskoj misiji u Parizu. Godine 1918. pohađao i kapetansku školu u Saint-Cyru i u početku zapovijedao 3. bataljunom 3. poljske pukovnije, a zatim je bio pomoćnik zapovjednika 2. pješačke pukovnije. Nakon što je Poljska ponovno stekla neovisnost, pridružio se organiziranoj poljskoj vojsci. Od studenoga 1918. do travnja 1919. zapovjednik bataljuna u 2. puhačkoj pukovniji Podhale, a zatim pomoćnik zapovjednika te pukovnije. Od 10. listopada 1919. služio je u 43. pješačkoj pukovniji, gdje je kao zapovjednik 3. bojne privremeno obnašao dužnosti zapovjednika pukovnije. Za sudjelovanje u ratu odlikovan je vojnim odlikovanjem Virtuti V. klase i Križem hrabrosti. U veljači 1921. poslan u Lavov na informativni tečaj za zapovjednike, nakon čega je prešao u Prvi pješački odjel Ministarstva vojnih poslova. Od 1923. započeo je službu u II. odjelu Generalštaba. Godine 1925. imenovan za vojnoga atašea u poljskoj misiji u Beogradu, uz istodobnu akreditaciju za Bugarsku. Tijekom boravka u Jugoslaviji promaknut u čin potpukovnika (1928.). Nakon povratka u zemlju u svibnju 1929. imenovan zapovjednikom 57. pješačke pukovnije. Nakon što je 1938. završio tečaj za šefa vojnoga učilišta promaknut je u čin pukovnika. Tijekom rujanske kampanje načelnik stožera Modlinske armije. Tijekom 1941./42. zapovjednik vojne organizacije koja je djelovala u okviru Saveza nacionalnih katoličkih organizacija „Unia”. Potom od 1943. do 1945. zapovjednik zapadnog sektora Domovinske vojske [Armii Krajowej], a zatim je 1946. kratko zapovijedao 16. pješačkom divizijom u poljskoj vojsci. Unaprijeđen je u čin brigadnoga generala. Umro je u Varšavi 2. prosinca 1946. i pokopan na vojnom groblju Powązki. CAW, KAP, sygn. 1769/89/1598, Grodzki Stanisław.

59 STAWECKI, „Attaché Wojskowi”, 130.

60 CAW, Oddz. II SG, sygn. I.303.4.126, Pismo Ministra Spraw Wojskowych gen Wł. Sikorskiego w sprawie powołania placówek w Belgradzie i Tokio.

61 CAW, Oddz. II SG, sygn. I.303.4.126, Pismo Szefa Oddziału II do Ministra Spraw Wojskowych nr 24901/II.Inf.A. z 10 stycznia 1925 r.
} 
da potpiše relevantne sporazume s Jugoslavijom. ${ }^{62}$ Ugovor je naposljetku potpisan 26. studenog $1925 .{ }^{63}$ i odnosio se na tajnu klauzulu poljsko-rumunjskoga sporazuma o savezništvu.

Tijekom mandata potpukovnika Grodzkog Poljska je s Kraljevinom SHS potpisala i pakt o prijateljstvu i suradnji, koji je bio važan za sigurnost države i poljsku vanjsku politiku. ${ }^{64}$ Zahvaljujući vještim naporima Grodzkog s uspjehom je pripremljen teren za razvoj komercijalnih aktivnosti u trgovini oružjem i streljivom. ${ }^{65}$ Kontakti i dobri odnosi koje je Grodzki razvio otvorili su put poljskim proizvođačima oružja. ${ }^{66}$ Treba napomenuti da to nije bio lak pothvat jer se poljska industrija oružja morala natjecati s jakim kompanijama poput češke Škode ili francuskoga Schneidera. Posebno opasni konkurenti bili su Česi, koji su imali veliki utjecaj u političkim i vojnim krugovima Kraljevine SHS.

Osim o vojnim aktivnostima, poljski ataše bio je autor brojnih izvještaja i o ekonomskom i socijalnom položaju Jugoslavije. Važne su njegove informacije iz rujna 1925. posvećene prometnoj strukturi jugoslavenske države. U uvodnom dijelu opisane su centralne i terenske institucije Ministarstva saobraćaja, a zatim cestovni, željeznički, riječni i morski te zračni promet. ${ }^{67}$

Međutim, glavni dio obavještajnoga rada u drugoj polovini dvadesetih godina bio je usmjeren na prikupljanje podataka o jugoslavenskoj vojsci.

Prema priručniku iz 1926., vojni ataše u Beogradu trebao je pribavljati podatke o sljedećim temama:

- Vojska Kraljevine SHS (uz ažuriranje postojećih podataka)

- mobilizacijske aktivnosti

- karakteristike zapovjednika Vojske Kraljevine SHS

- procjena stanja željezničke i cestovne infrastrukture države

- procjena statusa i mogućnosti riječnih luka Kraljevine SHS na Dunavu

62 CAW, Oddz. II SG, sygn. I.303.4.126, Wznowienie, naznaczenie personalne z 13 lutego $1925 \mathrm{r}$.

63 STĘPNIAK, Dyplomacja polska, 318.

64 „Pakt o prijateljstvu i srdačnoj suradnji između Republike Poljske i Kraljevine Jugoslavije” potpisali su 18. rujna 1926. u Ženevi ministri August Zalewski i Momčilo Ninčić. Isto, 321.

65 AAN, AW, sygn. AII/7, Informacja Attaché Wojskowego do Szefa Oddziału II z 24 października 1925 r. dotycząca działań w związku ze złożeniem ofert przez polskie przedsiębiorstwa przemysłu zbrojeniowego; AAN, AW, sygn. AII 13, t. 2. Eksport przemysłu obronnego do Jugosławii - Sprawozdanie za lata 1929-31 z 21 listopada $1931 \mathrm{r}$.

66 AAN, AW, sygn. AII/7, Informacja Attaché Wojskowego do Szefa Oddziału II z 24 października 1925 r. dotycząca działań w związku ze złożeniem ofert przez polskie przedsiębiorstwa przemysłu zbrojeniowego.

67 CAW, Oddz. II SG, sygn. I.303.4.7077, Informacja Attaché Wojskowego RP w SHS dot. Środki komunikacji w Królestwie SHS. Pismo nr 182/25 z dn. 25.09.1925 r. 
- stanje i razvoj industrije oružja Kraljevine SHS

- ustanovljavanje od koga i u kojim količinama Kraljevina SHS nabavlja sirovine za svoju industriju

- vanjska i unutarnja politika, ${ }^{68}$ posebno uzimajući u obzir odnose između Kraljevine SHS i njezinih susjeda, kao i velikih sila. ${ }^{69}$

Ured atašea bio je uključen i u prikupljanje podataka o pitanjima koja se odnose na komunikacijske linije i rute u Jugoslaviji i susjednim zemljama, posebno Rumunjskoj i Bugarskoj.

U ožujku 1927. poslana su četiri velika paketa radova u kojima je predstavljeno ustrojstvo centralnih vojnih vlasti, tj. Ministarstva vojske i mornarice, Generalštaba i institucija lokalne vojne uprave. ${ }^{70} \mathrm{U}$ sljedećim paketima proslijeđene su karakteristike pojedinih vrsta oružanih snaga, trupa i službi. Posebno zanimljivo opisane su pješadija, konjica, artiljerija i mornarica.

\section{Pješadija Kraljevine Srba, Hrvata i Slovenaca}

Osnovna taktička i upravna jedinica jugoslavenske pješadije bio je puk. U jugoslavenskoj vojsci u drugoj polovini dvadesetih godina pješadijski pukovi imali su po tri ili četiri bataljona.

Najčešći sastav jugoslavenskoga pješadijskog puka bio je sljedeći: zapovjednik puka sa štabom, vezna podjedinica, pionirska podjedinica ${ }^{71}$, sanitarna postrojba, 3-4 bataljona pješadije (streljačke), četa teških mitraljeza i pratećega naoružanja, administrativna i ekonomska podjedinica, skladište puka.

U mirnodopskom stanju jugoslavenska vojska trebala je imati pješadijski puk garde, 55 pukova linijske pješadije i pješadijski puk Boka kotorska. ${ }^{72}$ Sumirano, to je bilo oko 183 bataljona, tj. 732 streljačke čete i 55 četa teških mitraljeza. Pukovi linijske pješadije bili su dio 16. pješadijske divizije.

Po mišljenju poljskoga diplomata, pješadija Vojske Kraljevine SHS bila je organizirana prema srpskom iskustvu iz Prvoga svjetskog rata. Pukovnik

\footnotetext{
68 Više o sudjelovanju Ureda atašea u Beogradu u međunarodnim poslovima napisao je prof. Pepłoński. PEPŁOŃSKI, Wywiad a dyplomacja, 165.

69 AAN, AW, sygn. AII/8, Instrukcja dla Attaché w Belgradzie z 12 maja 1926 r.

70 AAN, AW, sygn. AII/10/1, „Wojsko Królestwa SHS”, Organizacja władz wojskowych Królestwa SHS.

71 Inženjerijska ili pionirska.

72 AAN, AW, sygn. AII/10/1, „Organizacja piechoty armii SHS”. Jednostka piechoty fortecznej. Pješadijski puk Boka kotorska služio je za obranu obale i, prema potpukovniku Grodzkom, bio je mobilizacijski zametak za stvaranje taktičkoga spoja čiji je zadatak bio obraniti jadransku obalu.
} 
Grodzki držao je da su organizacijska rješenja bila vrlo zanimljiva, a propisi dobri, ali ne i obuka.

Iznimno zanimljiv materijal koji je dopunjavao karakteristike jugoslavenske pješadije bio je opis poligonskih vježbi koje je poljski diplomat promatrao ujesen 1927. godine. Opisujući stanje pješadijske obuke, naglasio je upornost i hrabrost vojnika, no tvrdio je da jugoslavenska pješadija, s obzirom na to da raspolaže relativno novim borbenim sredstvima, ne umije iskoristiti svoj kapacitet, što je bio odraz loše pripreme oficira i višega vojnog zapovjedništva. Poljski ataše napisao je: „[...] Oficirski korpus u cjelini pokazao je znatne nedostatke u obuci. To se odnosi na sve vrste oružja." ${ }^{\text {"3 }}$ Bilo je nedostataka i u provođenju vježbi na razini čete i bataljona. Prema njegovim riječima, glavni razlog bila je neodgovarajuća kombinacija manevra i paljbe. Strogo se pridržavalo izvođenja vježbi u skladu sa šablonama iz 1914. godine. Primijetio je da je teren korišten u vrlo malenom stupnju, a da jedinice teškoga oružja nisu iskorištene. Usprkos tim brojnim i kritičkim napomenama izjavio je da se vojno zapovjedništvo jugoslavenske vojske dosta trudilo da bi riješilo nedostatke u obuci. ${ }^{74}$

\section{Konjica Kraljevine Srba, Hrvata i Slovenaca}

Jugoslavenska konjica bila je jednoličnoga tipa. Kao i u pješadiji, osnovna jedinica bio je puk. ${ }^{75}$

U periodu mira puk se sastojao od zapovjednika puka i štaba, četiri eskadrona, eskadrona teških mitraljeza, vezne jedinice i skladišta puka.

Eskadron je bio podijeljen na četiri voda, a vod na tri sekcije. Približan broj sastavnica jugoslavenskih konjičkih odreda iznosio je: 4 oficira, 10 podoficira, 94 razvodnika i 100 starijih razvodnika te 111 konja. Međutim, eskadron teških mitraljeza sastojao se od dva voda, od kojih je svaki imao dvije sekcije. U tom razdoblju konjički pukovi bili su u sastavu brigada, koje su bile raspoređene u dvije konjičke divizije. Svaka brigada imala je zapovjednika sa štabom i dva konjička puka. Dvije brigade sa zapovjednikom i štabom formirale su konjičku diviziju. Pored toga, divizija je uključivala konjički artiljerijski divizion i divizion (eskadrilu) pionira kao i ostale službe.

Konjica jugoslavenske vojske u doba mira sastojala se od dva zapovjedništva divizije, pet zapovjedništava brigada, dva puka konjičke garde i osam

\footnotetext{
73 CAW, Oddz. II SG, sygn. I.303.4.4132, 1-5. Pismo z 20.X.1927 r. do Szefa Oddziału II-go Sztabu Generalnego, Poselstwo Polskie w Belgradzie Attaché Wojskowy nr 259/27, 2.

74 Isto.

75 AAN, AW, sygn. AII/10/1, Organizacja kawalerii. Opracowanie „Organizacja wojska Królestwa SHS”.
} 
linearnih konjičkih pukova, što je ukupno davalo 40 konjičkih eskadrona i 10 eskadrona teških mitraljeza. Pukovnik Grodzki ocjenjivao je da je status obuke vrlo nizak. Napisao je da „[... je to jadna pješadija koja jaše na konjima [...]". ${ }^{76}$ Prema njegovu mišljenju, glavni razlog te negativne ocjene bio je nedostatak konjičke tradicije i iskustva u treniranju i organiziranju jahanja. Obuka je bila na niskoj razini, zapovjednici pojedinih stupnjeva, koji su najčešće potjecali iz austrougarske vojske, nisu davali veliku važnost svojim dužnostima. Drugi razlog lošega stanja jugoslavenske konjice, prema poljskom diplomatu, bilo je podcjenjivanje važnosti te vrste vojske od najviših zapovjednika oružanih snaga. ${ }^{77}$

\section{Artiljerija Kraljevine Srba, Hrvata i Slovenaca}

Jugoslavenska artiljerija bila je podijeljena na poljsku i tešku. Poljska artiljerija ${ }^{78}$ uključivala je topove kalibra do $155 \mathrm{~mm}$, a u tešku artiljeriju spadali su topovi i minobacači preko $155 \mathrm{~mm}$.

Prema taktičkim svrhama, artiljerija se dijelila na planinsku, poljsku, konjičku, protuzrakoplovnu, haubičku, dalekometnu i tvrđavsku. ${ }^{79}$

Osnovna jedinica artiljerije u jugoslavenskoj vojsci bila je baterija. Baterija se sastojala od četiri topa i imala je dva vatrena voda, svaki s po dva topa. U teškoj artiljeriji baterije su imale od 2 do 4 topa. Tri baterije formirale su artiljerijski eskadron. Dva do tri eskadrona formirala su puk, u čiji su sastav dodatno bile uključene sljedeće podjedinice: zapovjednik puka sa štabom, vezna jedinica, skladište puka i ostale službe. Najviši taktički spoj u artiljeriji bila je artiljerijska brigada, koja se sastojala od dva puka. U slučaju rata brigade ${ }^{80} \mathrm{su}$ trebale postati dio pješadijske divizije.

Kraljevska je vojska 1928. imala 32 divizijska artiljerijska puka, koji su bili podijeljeni u dvije skupine: prvu, s brojevima od 1 do 16 , činili su pukovi s tri divizije, a drugu, s brojevima od 17 do 32, pukovi s dvije divizije.

Osim toga kraljevska vojska imala je pet pukova teške artiljerije, od kojih je svaki bio na raspolaganju zapovjednicima armija, a tijekom rata trebao je biti artiljerijska potpora pri povlačenju.

\footnotetext{
76 Isto.

77 CAW, Oddz. II SG, sygn. I.303.4.4132, 3-4. Pismo z 20.X.1927 r. do Szefa Oddziału II-go...; AAN, AW, sygn. AII/10/1, Organizacja kawalerii. Opracowanie...

78 Terenska artiljerija dodatno se dijelila na poljsku laku i poljsku tešku. Prva je bila opremljena topovima i haubicama kalibra $100 \mathrm{~mm}$, a druga topovima i haubicama od 100 do $155 \mathrm{~mm}$.

79 AAN, AW, sygn. AII/10/1, Organizacją artylerii. Opracowanie „Organizacja wojska Królestwa SHS”.

80 Takva brigada sastojala se od dva puka mješovitoga sastava, od kojih je jedan imao tri, a drugi dvije divizije. Isto.
} 
Puk teške artiljerije sastojao se od zapovjednika sa štabom, dva diviziona s po dvije baterije svaki, vezne podjedinice i skladišta puka te drugih službi.

Jugoslavenska vojska imala je i jedan tvrđavski artiljerijski puk, koji je ulazio u sastav obalske odbrane i bio je pod zapovjedništvom Boke kotorske. ${ }^{81}$

Nedostatak kraljevske artiljerije bio je taj što je posjedovala mnogo različitih vrsta oružja i haubica. Ta raznolikost artiljerijske opreme utjecala je na kvalitetu tehničkoga korištenja i njezinih mogućnosti.

U citiranoj procjeni vježbi iz 1927. potpukovnik Grodzki naglasio je lošu opremljenost artiljerijskih podjedinica, nepoznavanje taktičkih pravila korištenja artiljerije i njezinu nepravilnu uporabu u borbi. ${ }^{82}$

Tridesetih godina pojačane su obavještajno-informacijske aktivnosti. Osim zadataka koje su obavljali diplomati iz veleposlanstava i ureda atašea u Beogradu, Bukureštu i Beču, u operativne aktivnosti uključeni su i agenti, posebno oni smješteni u Turskoj i Italiji. Proizlazilo je to prije svega iz ubrzanja rada na potpisivanju iznimno važna sporazuma o stvaranju strateških tranzitnih linija iz južne Europe do Poljske. Osim toga Jugoslavija je percipirana kao veliko tržište za prodaju poljske vojne opreme i naoružanja, iako je postojala svijest o poteškoćama zbog konkurencije francuskih i čehoslovačkih proizvođača oružja s veoma jakim položajem u jugoslavenskoj državi. Međutim, položaj koji su u Beogradu izgradili poljski diplomati tijekom dvadesetih godina davao je nadu za sklapanje ugovora o prodaji poljskoga vojnog materijala. Vojna pitanja i dalje su ostala u sferi zanimanja obavještajnih službi, posebno modernizacija kraljevskih oružanih snaga i aktivnost Beograda u sklopu Male Antante, kao i odnosi s Francuskom, Italijom, Mađarskom, Bugarskom, rastući utjecaj Njemačke i mogućnost izbijanja rata.

Vrlo zanimljiv dokument koji prikazuje stanje jugoslavenske države s početka tridesetih godina izvješće je potpukovnika Mieczysława Starzyńskog ${ }^{83}$

81 Isto.

82 CAW, Oddz. II SG, sygn. I.303.4.4132, s. 4. Pismo z 20.X.1927 r. do Szefa Oddziału II-go..., 4. „[...] Potpukovnik Grodzki procjenjuje da od negativnih strana korištenja topništva (osim lošega stanja konja i sanjki) treba spomenuti neprofesionalno vođenje borbenih operacija [...] Dodatnu zbrku unosi pozicioniranje topničkih položaja te skupine na $200 \mathrm{~m}$ od linije koju je zauzelo pješaštvo u obrani. Potpukovnik Grodzki procjenjuje se da negativne strane korištenja topništva (osim lošeg stanja konja i sanjke) treba spomenuti neprofesionalno vođenje borbenih operacija [...] Za dodavanje zabune ta skupina vjerojatno pada pozicioniranje topničkih položaja na udaljenosti od $200 \mathrm{~m}$ od linije zauzete od strane pješaštva u obrani."

83 Starzyński Mieczysław rođen je 22. srpnja 1891. u Varšavi. Njegov mlađi brat Stefan Starzyński bio je gradonačelnik Varšave. Nakon što je 1909. završio gimnaziju u Varšavi započeo je studij inženjerstva na Lavovskom veleučilištu. Godine 1910. pridružio se Savezu aktivnih borbenih i streljačkih saveza, pod kojim je završio časnički tečaj. Nakon izbijanja Prvoga svjetskog rata pridružio se poljskim legijama i najprije služi u dopunskom bataljunu u Krakovu, nakon čega je od siječnja 1915. dodijeljen 1., a potom 5. pješačkoj pukovniji poljske vojske. U neovisnoj poljskoj vojsci počeo je s činom poručnika pješaštva, sudjelujući u obrani Lavova. Tijekom rata 
(poljski vojni ataše u Beogradu 1929. - 1933.) o njegovu razgovoru s mađarskim vojnim diplomatom iz siječnja 1933. godine. Prema sačuvanom izvješću, Mađar je bio zainteresiran za razmjenu informacija u vezi s reorganizacijom jugoslavenske vojske, industrijom oružja i poljskom trgovinom oružjem s Kraljevinom Jugoslavijom. Osim toga iznio je stav Budimpešte prema Kraljevini, kao i zabrinutost stanjem unutarnjih odnosa u jugoslavenskoj državi. Diplomati su razgovarali i o odnosima Italije prema Jugoslaviji. Treba naglasiti da su se složili da budućnost Jugoslavije ovisi o rješavanju složenih nacionalnih i vjerskih pitanja. U analiziranom dokumentu potpukovnik Starzyński dao je i informaciju da doprema artiljerijske opreme iz Jugoslavije u Poljsku kasni zbog toga što zapovjednici artiljerijskih pukova nisu željeli predati oružje staroga tipa, objašnjavajući da im je potrebno najmanje nekoliko primjeraka za obuku na novoj opremi. ${ }^{84}$

Međutim, u srpnju 1932. poslao je opsežno izvješće u kojem obavještava o pokušaju pobune u mariborskom garnizonu (u 45. pp.). Iz podataka koje mu je dao pukovnik Petar Aračić (načelnik načelnik Obaveštajnog odeljenja Generalštaba Vojske Jugoslavije) proizlazi da je skupina oficira namjeravala izvršiti puč da bi izazvala nerede, što bi im omogućilo da opljačkaju novac iz filijale Narodne banke u Mariboru, a potom pobjegnu u Austriju. Poljski diplomat smatrao je te informacije izmišljenima jer je iz drugih izvora imao podatke o otkrivanju protuvladinih organizacija u ostalim garnizonima, uključujući Bihać i Mostar. ${ }^{85}$ Čini se da je procjena poljskoga vojnog atašea bila točna jer,

1919./20. sukcesivno obnašao dužnosti zapovjednika čete, šefa II. odjela Zapovjedništva okruga, šefa II. odjeljenja konjičke divizije i šefa odjeljenja II. odjela Generalštaba. Od siječnja do travnja 1920. pohađao je ratni tečaj Generalštabne škole. Nakon završetka Poljsko-ruskoga rata šef IV. odjela Korpusne oblasti, šef Sektora br. 4 (obavještajna služba) II. odjela Generalštaba u Krakovu, činovnik Armijskoga inspektorata br. IV, zapovjednik 2. bojne 12. pješačke pukovnije i časnik stožera Korpusnoga okruga br. V u Krakovu. Od lipnja 1926. do 19. siječnja 1928. služio u III. odjelu Generalštaba, isprva kao činovnik sekcije, a zatim šef odjeljenja. Dana 1. svibnja 1929. imenovan vojnim atašeom u poljskoj misiji u Beogradu, gdje je ostao do kraja 1933. godine. Tijekom boravka u inozemstvu promaknut 1. siječnja 1931. u čin potpukovnika. Nakon povratka u zemlju u ožujku 1934. premješten u rezervu. U rujnu 1934. postao pomorski vojvoda (wicewojewod), zatim u srpnju 1936. zamjenik glavnoga urednika, a od studenoga 1938. glavni urednik novina Gazeta Polska. Nakon izbijanja Drugoga svjetskog rata upravljao II. odjelom Zapovjedništva obrane Varšave. Po završetku rujanske kampanje sakrio se u zemlji, ali Nijemci su ga uhitili. Umro je 5. prosinca 1942. u Sachsenhausenu. CAW, KAP, sygn. I.340.1.229, s. 33; CYGAN, Oficerowie Legionów Polskich, 308-309.

84 AAN, Sz. Gł, sygn. 616/196, s. 1-5. Sytuacja wewnętrzna i zewnętrzna Jugosławii. Stosunki z jug.-węg. Rozmowa z węgierskim Attaché Wojskowym, Poselstwo Polskie w Belgradzie. Attaché Wojskowy Nr 64/33 z 23 stycznia 1933 r.

85 AAN, AW, sygn. AII/15/1, s. 1-3. Spisek w armji jugosłowiańskiej nr 388/32 z 11 lipca 1932 r. Poljski ataše izvijestio je da je pukovnik Petar Aračić „[...] kategorički izjavio da su sve vijesti o nekim postojećim zavjereničkim mrežama koje dopiru iz drugih garnizona bile puke glasine, tvrdio je da je cijela organizacija Miladinovića i Atanaskovića počinjala i završavala s Milojkovićem. [...] Aračić je izjavio da Milojković nije imao odnose ni sa jednom bečkom ili nacionalnom organizacijom te da nije primio nikakvu poruku koja bi mu naredila odgađanje”. 
prema Mili Bjelajcu, akcije oficira u mariborskom garnizonu najvjerojatnije su potaknuli komunisti. ${ }^{86}$

U srpnju i prosincu 1931. poljski ataše poslao je u Varšavu dvije zanimljive vojne informacije. Prva se odnosila na zrakoplovnu i protuzrakoplovnu artiljeriju, a druga je bila izvještaj o ordre de bataille $e^{87}$ kraljevske vojske. Prema informacijama, zrakoplovne i protuzrakoplovne jedinice prolaze reorganizaciju i proširenje. Starzyński je izjavio da Jugoslaveni intenzivno vježbaju. Jugoslavenska vojska bila je opremljena protuzrakoplovnim topovima $75 \mathrm{~mm}$ sistema Škoda. Osim toga, češki protuzrakoplovci trebali su otvoriti paljbu na poligonu na Prevlaci. ${ }^{88}$ Drugi dokument predstavio je ordre de bataille oružanih snaga Jugoslavije s podjelom na centralne institucije, zapovjedništva, obrazovanje, logistiku, radionice i tvornice oružja, kao i kopnene, zračne i mornaričke baze sa sjedištima štabova. ${ }^{89}$ Drugi oblik djelatnosti Ureda atašea u Beogradu bila je neposredna opservacija vojničkoga života tijekom službenih posjeta zapovjedništvima i garnizonima kraljevske vojske. Učinak takva putovanja majora Jana Grudzieńa u Skopje od 18. do 22. lipnja bilo je izvješće u kojem je opisao situaciju u okrugu III. armije. Osim karakteristika posjećenoga područja diplomat je predstavio i vojno-političku, demografsku i socijalnu situaciju na bugarskoj i albanskoj granici. ${ }^{90}$

U drugoj polovini tridesetih godina političke i vojne podatke o Kraljevini Jugoslaviji II. odjelu dostavila je obavještajna postrojba Capri, smještena pri poljskoj misiji u Rimu. Uz materijal koji se odnosi na političke odnose u vezi s hrvatskim pitanjem, poslane su aktualne informacije i šire analize vezane za vojnu aktivnost Italije u Albaniji te političke i vojne odnose Beograda sa Sofijom. ${ }^{91}$

Međutim, najzanimljivije podatke iz vojne sfere u proučavanom razdoblju isporučila je spomenuta ustanova Anitra, smještena u Turskoj. Godine 1934. dala je iznimno zanimljivu analizu vezanu za mobilizaciju jugoslavenske voj-

86 BJELAJAC, Vojska Kraljevine SHS, 171-172. O komunističkom utjecaju više u sjećanjima Andreja Zlobeca wątku komunistycznym szerzej we wspomnieniach Andreja Zlobeca: ZLOBEC, Častnik Kraljevine Jugoslavije, 127.

87 Franc. ordre de bataille, „bojni red”, može se prevoditi i kao bojni sustav, organizacijska shema oružanih snaga.

88 AAN, AW, sygn. AII/13/1, Organizacja lotnictwa lądowego i artyl.pl. armji jugosłowiańskiej, nr L. dz. 388/31.wojsk. z 7 lipca 1931 r.

89 AAN, AW, sygn. AII/13/1, L'ordre de bataille de l'armée Yougoslave à la date du $1^{\text {-er }}$ décembre 1931, Poselstwo Polskie w Belgradzie. Attaché Wojskowy Nr 702/31 z 24.XII.1931 r.

90 AAN, Sz. Gł, sygn. 616/224, 1-3, Raport z podróży do Skoplje. Poselstwo Polskie w Belgradzie. Attaché Wojskowy Nr 206/34 z 29 czerwca 1934 r.

91 CAW, Oddz. II SG, sygn. I.303.4.4030, Informacja z Poselstwa Jugosł. w Rzymie, nr 56/1472/ 8.III.1937 r.; Fortyfikowanie przez Albańczyków północno-wschodniej części państwa nr 78/1494 z 20.III.1937 r.; Informacja nr 92/1058 z 31.III.1937 r.; Stosunki włosko-jugosłowiańskie, 93/1059 z 31.III.1937 r.; Porozumienie włosko-jugosłowiańskie, 100/1525 z 19.VI.1937 r. 
ske zbog pogoršanja političke situacije u srednjoj Europi i na Balkanu. Opisala je postupak popunjavanja trupa s mirovnih na ratne potrebe i planirano koncentriranje oružanih snaga u slučaju rata. ${ }^{92} \mathrm{U}$ zaključcima je rečeno da je većina aktivnih tijela trebala biti koncentrirana u pograničnom području s Italijom, a ostali operativni sektori tretirani su kao štit. Na jugu zemlje koncentrirana je znatna strateška formacija za povlačenje, koja se sastojala od pet pješadijskih i jedne konjičke divizije. To je pokazivalo da su političke i vojne vlasti smatrale Italiju najvećom prijetnjom Kraljevini. Ta demonstracija snage trebala je i pokazati susjedima Jugoslavije da je spremna prihvatiti bilo koji izazov, uključujući i rat. ${ }^{93}$ Vrlo zanimljivo izvješće dostavljeno je 11. studenog 1934. godine. To je bila rasprava o vježbama konjičkih jedinica u okolici Niša. U njima su sudjelovala dva puka, artiljerijska grupa, planinski pješadijski bataljon i izviđački eskadron. Glavna svrha vježbi bile su izviđačke aktivnosti koje su u borbenim uvjetima izvodile konjica i zračne jedinice. Prema kratkoj procjeni, manevri su postigli svoj cilj, ali je ustanovljeno da je potrebno nastaviti obuku sa svim konjičkim jedinicama. ${ }^{94}$

Sljedeće godine Anitra je podnijela niz izvještaja prije svega o modernizaciji usmjerenoj na usavršavanje vojske u formiranju podjedinica oklopnih (brzih) trupa, ${ }^{95}$ izgradnju novih komunikacijskih linija, reorganizaciju pješadijskih pukova i zračnih postrojbi. ${ }^{96}$ Poslana je i vrlo vrijedna analiza rastućega njemačkog utjecaja u Jugoslaviji, koja opisuje brojne posjete vojske i diplomata Trećega Reicha Kraljevini i procjenjuje pronjemačku politiku premijera Milana Stojadinovića. ${ }^{97}$

Godine 1936. u Varšavu je poslano nešto više od desetak studija i izvještaja posvećenih modernizaciji protuplinskih ${ }^{98}$ podjedinica i širenju zračnih snaga Jugoslavije. U informacijama o protukemijskim (plinskim) obrambenim jedinicama istaknuto je da bi zbog talijanskoga iskustva borbe u Abesiniji sustav protuplinske obrane u zemlji trebao biti reorganiziran. Posebnu ulogu u

92 CAW, Oddz. II SG, sygn. I.303.4.3966, Depesza-Szyfr z Belgradu dn. 16.X.1934 r.; CAW, Oddz. II SG, sygn. I.303.4.1921, s. 1-5, 6-8. Mobilisation les nouvelles mesures prises par l'Etat - Major General par suite du changement de la situation en Europe Centrale, 27.XI.1934 r.

93 CAW, Oddz. II SG, sygn. I.303.4.1921, s. 1-5, 8.

94 CAW, Oddz. II SG, sygn. I.303.4.1918, 1-2. Manoeuvres de cavalerie dans la région de Nisch.

95 CAW, Oddz. II SG, sygn. I.303.4.1919, 1. Informations Diverses z 10.IX.1935 r.; CAW, Oddz. II SG, sygn. I.303.4.1919, 1-2. Informations Diverses z 14.X.1935 r. Prema tim podacima, automobilske podjedinice trebale su biti formirane u beogradskom garnizonu i u Osijeku, gdje je trebalo formirati tenkovsku diviziju (5-6 tenkova tipa Renault NC. 27) pri 1. konjičkoj diviziji.

96 CAW, Oddz. II SG, sygn. I.303.4.1919, Informations Diverses z 10.IX, 3-5.

97 CAW, Oddz. II SG, sygn. I.303.4.1919, 2-5. L'orientation secrete de la politique Yougo-slave de les efforts de la propagande Nazi en Yougo-slave, 14.X.1935 r.

98 CAW, Oddz. II SG, sygn. I.303.4.1920, s. 1-4. La reorganisation des unites des gaz dans l'armee. 
tom sistemu imaju specijalističke vojne protuplinske podjedinice, zbog čega se smatralo da ih treba ojačati. ${ }^{99}$ Počevši od prepiske s kraja 1936., stavljao se osobit naglasak na razvoj odsjeka i podjedinica koji bi mogli učinkovito suzbiti kemijski napad; smatralo se da su posebno ugrožene tvornice za proizvodnju kemijskih proizvoda. Točno je primijećeno da javnost može biti meta zračnoga ili artiljerijskoga napada, ali i da postoji prijetnja vezana za industrijska postrojenja koja proizvode ili skladište kemikalije zbog mogućnosti kontaminacije, npr. nakon bombardiranja ili artiljerijskoga granatiranja. ${ }^{100}$

Poslano je nekoliko dokumenata vezano za razvoj zrakoplovstva. Jedan od njih odnosio se na reviziju zrakoplovne opreme koja je bila na raspolaganju nevojnim organizacijama, paravojnim, privatnim i zrakoplovnim obrazovnim centrima, a bila je namijenjena korištenju tijekom rata. Smatralo se da se dio te opreme može upotrijebiti za obuku i izviđačke aktivnosti pješaštva. ${ }^{101} \mathrm{U}$ sljedećem dokumentu opisan je posjet francuskoga generalnog inspektora zračnih snaga Pierrea Martinot-Lagardea i predstavljen kratak opis tema razgovora koji su se odnosili na tehničku suradnju i nabavu francuske opreme za jugoslavensko zrakoplovstvo. Isto izvješće govori i o pitanjima vezanim za probleme sa zrakoplovnim motorima i razmatra projekt novoga borbenog zrakoplova IK-9. ${ }^{102}$

U II. odjel poslana su opsežna izvješća, uključujući i podatke o mornaričkim vježbama, nabavi novih oklopnih drezina marke Škoda i protuzračnih vježbi u niškom garnizonu (sudjelovale su dvije baterije topova $75 \mathrm{~mm}$ ), ${ }^{103} \mathrm{kao}$ i izvještaji o promjenama $u$ artiljerijskim izviđačkim jedinicama ${ }^{104}$ i teškoj motorizaciji ${ }^{105}$. Opisane su i glavne strateške linije na području Jugoslavije i ocijenjena je njihova važnost za ratne planove Kraljevine. ${ }^{106}$

Tijekom opisanoga razdoblja u informativnim i obavještajnim izvješćima Ureda atašea dominiraju političko-vojna i politička pitanja koja se odnose na trenutačnu međunarodnu situaciju na Balkanu i u njegovu susjedstvu. Važno mjesto u obavještajnom radu kasnih tridesetih godina XX. stoljeća imaju u prvom redu podaci o talijanskim aktivnostima u Albaniji i političkoj ekspanziji nacističke Njemačke, kao i pronjemačka politika kraljevske vlade. Posljednji

\footnotetext{
99 Isto, 1-2.

100 Isto, 1.

101 CAW, Oddz. II SG, sygn. I.303.4.1920, 1-2. Liste des avions prives insgrit à l'aeronautique Yougo-slave.

102 Isto.

103 CAW, Oddz. II SG, sygn. I.303.4.1920, 1-2. Informations Diverses z X.1936.

104 CAW, Oddz. II SG, sygn. I.303.4.1920, 1-2. L'organisation des peloton de mesurage au près des regiments d'artillerie Yougo-slave en paix et guerre.

105 CAW, Oddz. II SG, sygn. I.303.4.1920, 1-2. La motorisation des unites de l'artillerie lourde. 106 CAW, Oddz. II SG, sygn. I.303.4.1920, 1-2. Construction des grandes lignes strategiques.
} 
poljski vojni ataše, pukovnik Tadeusz Wasilewski ${ }^{107}$, stvarao je obavještajne $\mathrm{i}$ kurirske strukture pripremajući se za rat. Do kraja svoje misije u Beogradu bavio se uz ostalo prebacivanjem poljskih vojnika nakon rujanskoga poraza. ${ }^{108}$

\section{Zaključak}

Oružane snage Kraljevine Jugoslavije nikako nisu bile glavni cilj obavještajnih aktivnosti II. odjela Glavnoga stožera poljske vojske, no ipak su aktivno prikupljane informacije o stanju trupa, njihovu naoružanju, opremi i obuci. Vojni analitičari primjećivali su promjene koje su se događale u jugoslavenskim oružanim snagama, upozoravajući na proces modernizacije u motorizaciji, mornarici i zračnim snagama. Uočili su i nedostatke i poteškoće s kojima se kraljevska vojska morala suočiti, ističući prije svega slabu obuku oficira, osobito na operativnoj i operativno-taktičkoj razini. Uočeni su i drugi problemi, koji se odnose na nedostatak ujednačenoga naoružanja i artiljerije i nedostatke u tehničkoj opremi, posebno u veznoj, inženjerskoj i protuplinskoj opremi.

Pored čisto vojnih pitanja, i agente i diplomate Druge Republike Poljske zanimale su informacije o unutarnjem i vanjskom stanju Kraljevine SHS / Jugoslavije. Podaci o njezinoj politici i odnosima s drugim državama, posebno Čehoslovačkom, Bugarskom i Rumunjskom, bili su potrebni za stvaranje poljske strategije. Političke i političko-vojne informacije s područja Balkana dobile su posebnu važnost u vezi s ubrzanjem stvaranja pravnih temelja za izgradnju strateškoga koridora koji povezuje Poljsku s egejskom obalom, kao i porastom aktivnosti i utjecaja Trećega Reicha u Jugoslaviji i Bugarskoj, što je zabilježeno već 1934. godine. Ovisnost jugoslavenske države o Berlinu promatrana je sa zabrinutošću i u političkoj i u vojnoj sferi. Brojni posjeti njemačkih zapovjednika Beogradu i Jugoslavena Njemačkoj, prodaja oružja,

107 Tadeusz Adam Wasilewski rođen je 30. siječnja 1897. godine. Pješački časnik. Tijekom 1917./18. služio u 1. poljskom korpusu u Rusiji. Nakon rata pridružio se obnovljenoj poljskoj vojsci. Kao poručnik služio u 22. pješačkoj pukovniji u Siedlcu, s kojom je sudjelovao u vojnim operacijama tijekom Poljsko-ruskoga rata. Od 1921. do 1923. studirao na Višoj vojnoj školi, gdje je bio student 2. smjera. Sredinom dvadesetih služio u III. odjelu Ureda Ratnoga vijeća. Između 1927. i 1932. zapovjednik čete u Korpusu granične zaštite (KGZ) i načelnik stožera brigade KGZ-a u Vilniusu. Od 1932. do 1934. zapovijedao 1. bataljunom u 16. pješačkoj pukovniji u garnizonu Tarnów, a zatim do 1937. načelnik stožera 27. pješačke divizije u Kovelu u Volinskoj oblasti. U travnju 1937. imenovan za vojnoga atašea u poljskoj misiji u Jugoslaviji, uz istodobnu akreditaciju za Bugarsku. Nakon izbijanja rata postao šef II. odjela Stožera glavnoga zapovjednika poljske vojske. Tijekom 1940./41. načelnik stožera 1. streljačke brigade u Škotskoj. Godine 1941. ponovno imenovan vojnim atašeom u Jugoslaviji, što je bio do 1945. godine. Od 1946. do 1948. služio u Poljskom preseljeničkom korpusu. Za sudjelovanje u ratu 1919./20. nagrađen Srebrnim križem Virtuti militari V. klase. Umro je 1964. godine. MILEWSKI, SUCHCITZ, GORCZYCKI, Guide to the Archives, 291.

108 WASILEWSKI, „Z dziennika attaché wojskowego w Belgradzie”, 43-46. 
posebno njemačkih zrakoplova, i obavještajni prodor u Jugoslaviju bili su predmet mnogih izvještaja i poruka poslanih iz Beograda. Približavanje jugoslavenske vlade Njemačkoj moralo je utjecati na politiku poljskih vlasti kao i na odluke vezane uz državnu sigurnost. Stoga je poljska vojna obavještajna služba pomno promatrala razvoj situacije na Balkanu i u pojedinim zemljama poluotoka. Jugoslavija je nesumnjivo bila važan obavještajni objekt za Drugu Republiku Poljsku. 


\section{Arhivski i neobjavljeni izvori}

AAN, AW: Archiwum Akt Nowych, Attachés wojskowi RP przy rządach państw kapitalistycznych.

AAN, Sz. Gł: Archiwum Akt Nowych, Sztab Główny 1918-1939.

CAW, KAP: Centralne Archiwum Wojskowe, Kolekcja Akt Personlanych.

CAW, Oddz. II SG: Centralne Archiwum Wojskowe, Oddział II Sztabu Generalnego (Głównego) 1921-1939.

\section{Literatura}

BATOWSKI, Henryk. Między dwiema wojnami 1919-1939. Zarys historii dyplomacji. Kraków: Wydawnictwo Literackie, 2001.

BATOWSKI, Henryk. Rozpad Austro-Wegier 1914-1918. Sprawy narodowościowe i działania dyplomatyczne. Kraków: Wydawnictwo Literackie, 1982.

BJELAJAC, Mile. Vojska Kraljevine SHS/Jugoslavije 1922-1935. Beograd: Institut za noviju istoriju Srbije, 1994.

CYGAN, Wiktor Krzysztof. Oficerowie Legionów Polskich 1914-1917. Słownik biograficzny, tom IV, P-S. Warszawa: Barwa i Broń, 2006.

KOŁAKOWSKI, Piotr. Czas próby. Polski wywiad wojskowy wobec groźby wybuchu wojny w 1939 roku. Warszawa: Wydawnictwo DEMART, 2012.

KOŁAKOWSKI, Piotr. Między Warszawa a Praga. Polsko-czechosłowackie stosunki wojskowo-polityczne 1918-1939. Warszawa: Bellona, 2007.

KRZAK, Andrzej. „Attachat Wojskowy w Belgradzie w dwudziestoleciu międzywojennym”. Bezpieczeństwo. Teoria i praktyka (2008), br. 3-4: 231-243.

KRZAK, Andrzej. Czerwoni Azefowie. „Afera MOCR-TRUST” 1922-1927. Warszawa: Wojskowe Centrum Edukacji Obywatelskiej, 2010.

LARECKI, Jan. Wielki leksykon służb specjalnych świata. Organizacje wywiadu, kontrwywiadu i policji politycznych świata, terminologia profesjonalna i żargon operacyjny. Warszawa: Wydawnictwo Książka i Wiedza, 2007.

LECZYK, Marian. Polska i sasiedzi. Stosunki wojskowe 1921-1939. Białystok: UW. Filia w Białymstoku, 1997.

ŁOSSOWSKI, Piotr. Dyplomacja polska 1918-1939. Warszawa: Oficyna Wydawnicza ASPRA-JR, 2001. 
MILEWSKI, Wacław; SUCHCITZ, Andrzej; GORCZYCKI, Andrzej. Guide to the Archives of the Polish Institute and Sikorski Museum, vol. I. London: Orbis Books, 1985.

PEPŁOŃSKI, Andrzej. Wywiad a dyplomacja II Rzeczpospolitej. Toruń: Wydawnictwo Mado, 2004.

PEPŁOŃSKI, Andrzej. Wywiad Polski na ZSRR 1921-1939. Warszawa: Bellona, 1996.

STAWECKI, Piotr. „Attaché Wojskowi Drugiej Rzeczpospolitej”. Przegląd Historyczno-Wojskowy (2004), br. : 107-138.

STĘPNIAK, Władysław. Dyplomacja polska na Bałkanach 1918-1926. Warszawa: Naczelna Dyrekcja Archiwów Państwowych, 1998.

WANDYCZ, Piotr. Z dziejów dyplomacji. Londyn: Wydawnictwo Polonia, 1988.

WASILEWSKI, Tadeusz. „Z dziennika attaché wojskowego w Belgradzie”. Goniec Karpacki (1959), br. 2-3: 43-46.

WOJTASZCZYK, Konstanty A., ur. Polskie Służby Specjalne. Słownik. Warszawa: Oficyna Wydawnicza ASPRA-JR, 2011.

ZLOBEC, Andrej. Častnik Kraljevine Jugoslavije. Ljubljana: Samozal. D. Kunaver, 2010.

ZNAMIEROWSKA-RAKK, Elżbieta. „Koncepcje dróg strategiczno-tranzytowych na obszarze Europy Środkowo-Wschodniej w polityce polskiej i międzynarodowej okresu międzywojennego". Studia z Dziejów Rosji i Europy Środkowo-Wschodniej (1995), t. XXX. 


\section{SUMMARY}

\section{The Political and Military Situation and the Armed Forces of the Kingdom of Serbs, Croats and Slovenes / Yugoslavia in the Information, Reports, and Analyses of the Management of Intelligence and Reconnaissance Intelligence of the Main Staff of the Army of the Republic of Poland}

The Kingdom of Serbs, Croats and Slovenes / Yugoslavia was not a major subject of the operational activities (main operational objective) of the Polish military intelligence. Nonetheless, due to the implemented and planned strategic projects related to national defence, assignments were made to collect data, primarily on the military potential of the country, its politics towards neighbouring states, and the possibility of selling Polish arms to it. There is no doubt that the leadership of Poland and the intelligence officers were interested in the secret expansion of the Yugoslav army and its political and military relations with Czechoslovakia and Romania within the frame of its obligations as part of the Little Entente. The analysed documents show that the Polish army saw Yugoslavia as a state with complicated internal relations that seeks to preserve the Versailles order and has numerous scholarly and cultural ties with Poland. On the other hand, they detected Yugoslavia's sympathy for Russia, Czechoslovakia, and Germany as well as its numerous White Guard diaspora, which was seen as an element infiltrated there by the Bolsheviks, and this certainly also influenced the decision that the Kingdom of Yugoslavia should be included in the intelligence activities of the Management of Intelligence and Reconnaissance Intelligence (P2) in order to evaluate its politics and military capabilities.

Key words: Management of Intelligence and Reconnaissance Intelligence; military attaché; Royal Yugoslav Army; military diplomacy; intelligence and information activities 